\title{
CORALLINA INCRASSATA.
}

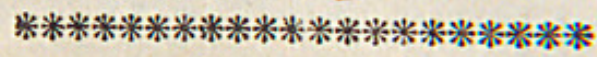 \\ CHARACTER GENERICUS.
}

Animal? crescens habitu plantæ.

Stirps fixa. Rami articulati, ramulosi.

$$
\text { CHARACTER SPECIFICUS, E`c. }
$$

Corallina incrassata. C. trichotoma articulata, articulis compressis convexo-planis cuneiformibus.

Corallina incrassata.

$$
\text { Lin. Syst. Nat. Gmel. }
$$

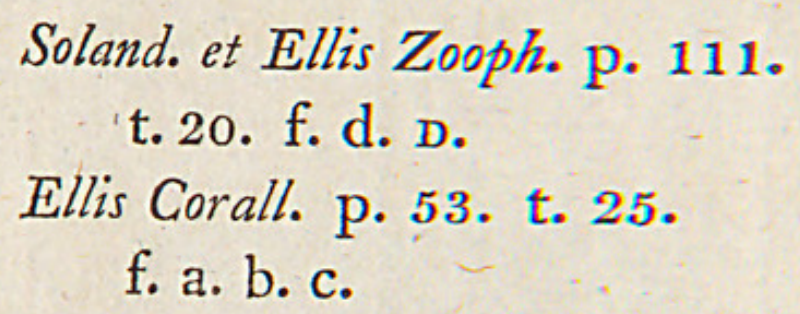

Circa litora insularum Americanarum non raro conspicitur Corallina incrassata, cujus veram magnitudinem cernere est in tabula. 
'ATARES SOMT AWIJATOO

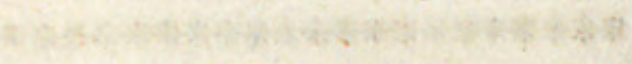

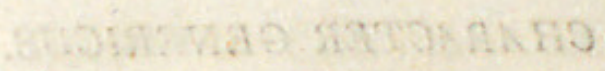

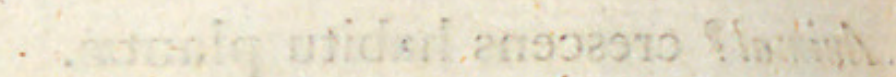

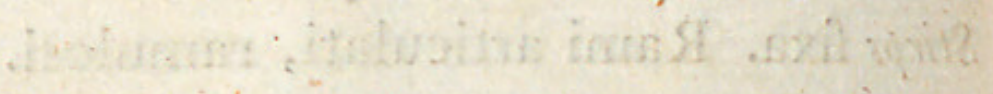

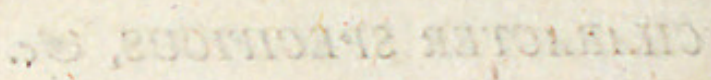

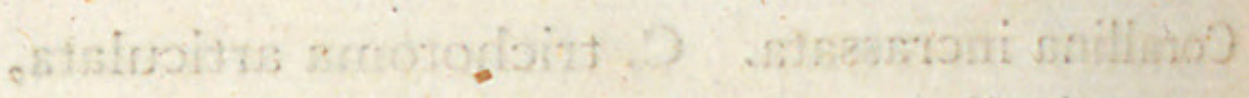

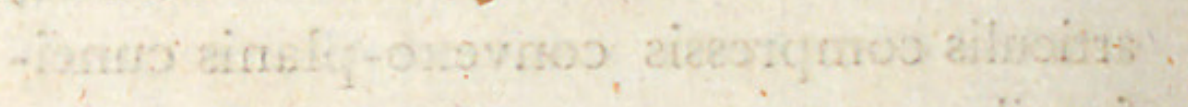

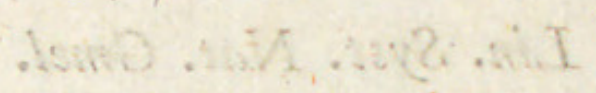

cudimat

- Sicachioni snilliso?

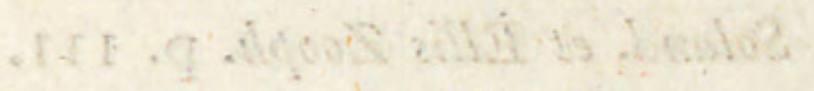

$$
\begin{aligned}
& \text {.6. Q. . . .02. . }
\end{aligned}
$$

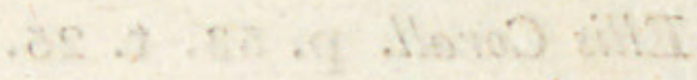

$$
\begin{aligned}
& \text { o.d an } 3
\end{aligned}
$$

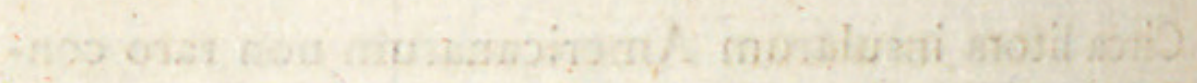

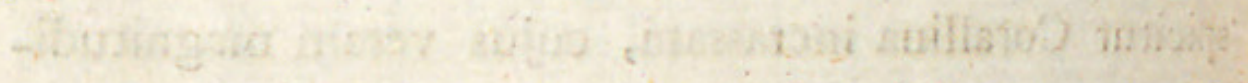

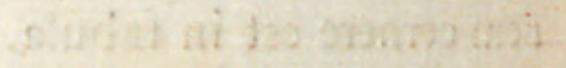

$\because$ 



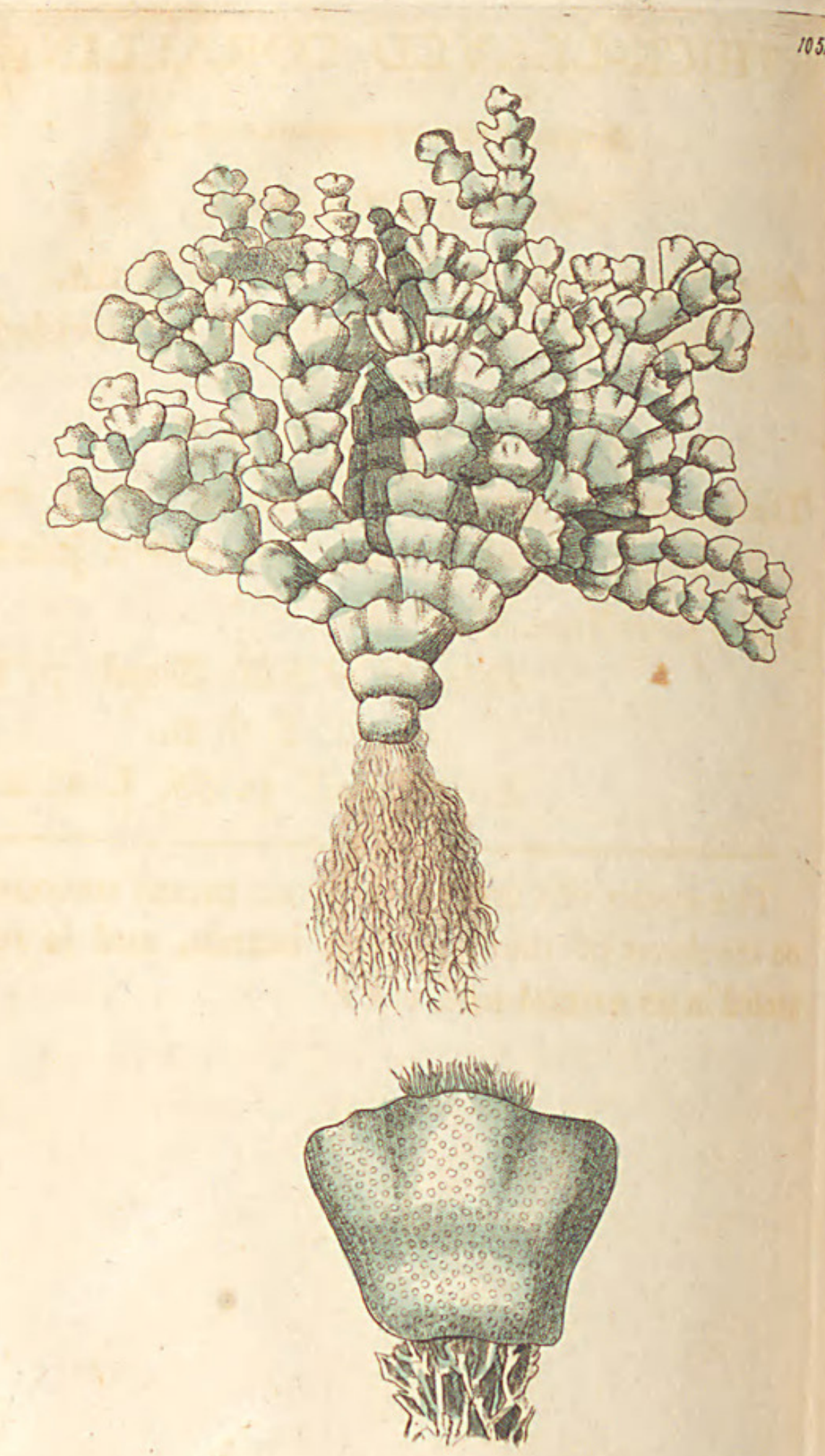




\section{THE \\ THICK-LEAVED CORALLINE.}

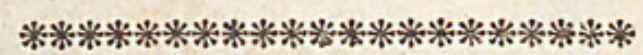

GENERIC CHARACTER.

Animal? growing in the form of a Plant. Stem fixed: branches jointed and subdivided.

SPECIFIC CHARACTER, छC.

Trichotomous jointed Coralline, with compressed, plano-convex cuneiform joints. Fleshy Coralline.

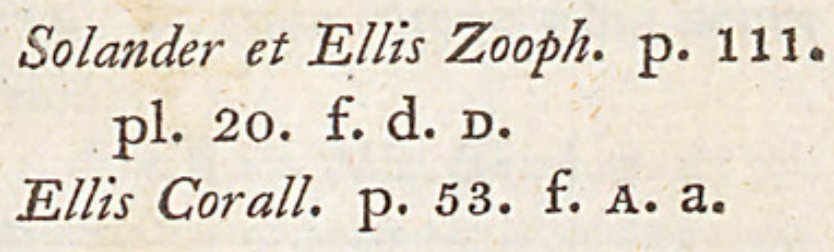

This species of Coralline is by no means uncommon on the shores of the American islands, and is represented in its natural size. 


\section{$2 \mathrm{BHL}$ Biodiversity Heritage Library}

Shaw, George. 1813. "Corallina incrassata, The Thick-leaved Coralline [PI. 1051]." The Naturalist's Miscellany 24(CCLXXXIV), -.

https://doi.org/10.5962/p.322331.

View This Item Online: https://www.biodiversitylibrary.org/item/296719

DOI: https://doi.org/10.5962/p.322331

Permalink: https://www.biodiversitylibrary.org/partpdf/322331

\section{Holding Institution}

Museums Victoria

\section{Sponsored by}

Atlas of Living Australia

\section{Copyright \& Reuse}

Copyright Status: Public domain. The BHL considers that this work is no longer under copyright protection.

This document was created from content at the Biodiversity Heritage Library, the world's largest open access digital library for biodiversity literature and archives. Visit BHL at https://www.biodiversitylibrary.org. 